\section{Australian Journal of \\ Crop Science}

AJCS 15(07):970-976 (2021)

doi: 10.21475/ajcs.21.15.07.p2498
AJCS

ISSN:1835-2707

\title{
Morphophysiological responses of table beet irrigated with saline water under application of humic substances
}

\author{
Leandra de Melo Cavalcante Sousa ${ }^{1}$, Thiago Jardelino Dias ${ }^{2}$, Lunara de Sousa Alves ${ }^{1}$, Mário Leno Martins \\ Véras $^{3}$, Ygor Henrique Leal ${ }^{1}$, Anderson Carlos de Melo Gonçalves ${ }^{4}$, Ewerton Gonçalves de Abrantes ${ }^{5}$, \\ Adriano Silvano Lopes ${ }^{1}$, Marcos Fabrício Ribeiro Lucena ${ }^{2}$, Lucas Soares Rodrigues ${ }^{2}$
}

${ }^{1}$ Federal University of Paraíba, Department of Phytotechnics and Environmental Sciences, Highway BR 079 - km 12, 58397-000, Areia, PB, Brazil

${ }^{2}$ Federal University of Paraíba, Department of Agriculture, 58220-000, Bananeiras, PB, Brazil

${ }^{3}$ Federal Institute of Amapá, Highway BR 210, km 103, Porto Grande, AP, Brasil

${ }^{4}$ Federal University of Roraima, Boa Vista, RR, Brazil

${ }^{5}$ Federal University of Paraíba, Department of Soil and Rural Engineering, Highway BR $079-\mathrm{km} 12$, 58397-000, Areia, PB, Brazil

*Corresponding author: lunara_alvesuepb@hotmail.com

\begin{abstract}
The use of saline water is an alternative for irrigating agricultural crops, especially in the Brazilian Northeastern semi-arid region, where water quality is limited in most cases. Thus, the objective was to evaluate the morphophysiological responses of table beet cv. "Wonder" irrigated with saline waters under the application of humic substances. The experiment was conducted under a randomized block design, with six replications in a $6 \times 4 \times 5$ factorial scheme, referring to six electrical conductivities of irrigation water (ECW): $0.5 ; 1.5 ; 2.5 ; 3.5 ; 4.5$ and $5.5 \mathrm{dS} \mathrm{m}^{-1}$, four humic substances rates (HS) $(0 ; 10 ; 20$ and $30 \mathrm{ml}$ per plant), and five stages of assessment $(23,38,53,68$ and 83 days after emergency). The characteristics evaluated were: plant height, number of leaves, leaf area, chlorophyll content ( $\mathrm{a}, \mathrm{b}$ and total), stomatal conductance, transpiration, net photosynthesis and $\mathrm{CO}_{2}$ internal concentration, and in the soil, the soil pH and the electrical conductivity of saturated paste extract. The increase of salinity reduced growth, chlorophyll a content, and the stomatal conductance of beet plants. The application rate of $30 \mathrm{ml}$ per plant of humic substances promotes an increase in stomatal conductance. The application of humic substances raises the $\mathrm{pH}$ in sandy acidic soils. It is recommended to irrigate table beet plants with water of $0.5 \mathrm{dS} \mathrm{m}^{-1}$ associated with the application of $30 \mathrm{~mL}$ per plant of humic substances.
\end{abstract}

Keywords: Beta vulgaris L.; humic acids, salinity; gas exchange.

Abbreviations: HS_humic substances; ECW_electrical conductivity of irrigation water; DAE_days after emergence; $\mathrm{Cl}$ a_chlorophyll a; $\mathrm{Cl}$ b_chlorophyll b; $\mathrm{Cl}$ total_total chlorophyll; A_net photosynthesis; Gs_stomatal conductance; $\mathrm{Ci}_{-} \mathrm{CO}_{2}$ internal concentration; E_transpiration rate; ECspe_electrical conductivity of saturated paste extract.

Introduction

Salinity is one of the factors that cause the most limitation in crop production, and causes severe restriction in physiological activities and in the productive potential of cultivated plants. (Taiz et al., 2017). This occurs mainly in prone areas of drought, rainfall irregularities and high temperatures. Due to these factors, the low availability of good quality water is the main limiting factor for agriculture in the Brazilian semi-arid region, with negative impacts on production (Freire et al., 2014). Thus, the use of saline water for irrigation has been a challenge for rural producers and researchers, who are constantly developing studies to enable the use.

One way to mitigate the harmful effects of saline water on agriculture is the use of organic inputs, such as humic substances. Studies have shown that the use of humic acids has provided several benefits in the chemical and biochemical processes of the soil, such as in the plant's nutrient absorption capacity, in cations complexing and transporting, and in physiological reactions in microorganisms and plants (Mora et al., 2010; Zandonadi et al., 2014). In addition to positive effects on the growth and development of some crops such as beans (Aydin et al., 2012), cucumber (Karakurt et al., 2015), maize (Kaya et al., 2018), almond (Hatami et al., 2018), and sorghum (Ali et al., 2019), and beet cultivation, as observed in studies carried out by Rassam et al., (2015) and Wilczewski et al., (2018). Some studies indicate that humic substances have auxin-like activity (Canellas et al., 2002; Nardi et al., 2002; Zandonadi et al., 2007), as well as in mitigating the effects of salinity (Khaled and Fawy, 2011; Jarošová et al., 2016; Saidimoradi et al., 2019).

In the face of few studies showing the effects of humic substances in vegetables grown in saline conditions, the 
relevance for irrigated agriculture is observed, especially for semi-arid regions, in order to develop strategies to mitigate the effects of excess salts and increase the efficiency and preservation of the production system. Thus, the objective of this study was to evaluate the effect of humic substances on the development and physiology of table beet, and on the soil, under irrigation with saline water.

\section{Results and discussion}

The growth parameters of plant height, number of leaves and leaf area were significant for the stage of assessments (SoA) at $5 \%$ probability. $(p<0,05)$ (Table 3$)$. There was an effect of the stage of assessments (SoA) $(p<0.05)$ for the levels of chlorophylls a $(\mathrm{Cl} a), b(\mathrm{Cl} b)$ and total (Total $\mathrm{Cl})$, and there was interaction between the humic substances rates (HS) and the stage of assessments $($ SoA $)$ for chlorophyll content $a(p<0.05)$ (Table 4).

The humic substances rates (HS) significantly influenced the stomatal conductance $(G s)(p<0.05)$, while there was an effect of the stages of assessment (SoA) for the stomatal conductance (Gs), $\mathrm{CO}_{2}$ internal concentration ( $\mathrm{Ci}$ ), and the transpiration rate (E) (Table 5), with interaction HS x SoA for $\mathrm{Ci}$. The levels of electrical conductivity in irrigation water $(E C w)$ significantly influenced $(p<0.05)$ the electrical conductivity of the saturation paste extract (ECspe), while the HS rates influenced the $\mathrm{pH}(\mathrm{p}<0.05)$, and there was no interaction between the factors for ECspe and $\mathrm{pH}$. (Table 6).

\section{Effect of humic substances rates, saline water and stages of} assessment on growth parameters

The height of the beet plant increased as a result of the evaluation stages, with growth up to 64 days after emergency (DAE), with a value of $38.74 \mathrm{~cm}$, remaining constant until 83 DAE (Figure 1A). This observed behavior occurs because the beet plants continues to emit leaves until the end of the cycle, and the older leaves enter the senescence process, which is related to the physiological cycle of the crop. The result came close to what was found by Alves et al. (2008), that evaluating the beet in hydroponic cultivation, verified the height of 40.5 $\mathrm{cm}$ at 63 days after sowing, and were lower than that found by Gondim et al. (2010), who also working with hydroponic beet cultivation, observed that the plants reached $49.58 \mathrm{~cm}$ in height at 60 DAE. Humic substances reduce the damage caused by salinity in fennel, as observed by Zulfiqar et al., (2019), who observed significantly taller plants using humic substances, with an increase of $23 \%$ compared to the control. In research of Sani (2014), it was observed that leaf application of humic acid promoted positive results in the height of the plant and in the number of leaves of canola plants.

The number of leaves increased with a quadratic trend up to $53 \mathrm{DAE}$, with a maximum value observed at $38 \mathrm{DAE}$, of 7.7 leaves per plant (Figure 1B). At $38 \mathrm{DAE}$, the beet plants begin to emit the tuber, where nutrients are being accumulated, thus decreasing the translocation of nutrients to the aerial part of the plant, and consequently restricts the production of new leaves. Results differ from those found by Gondim et al. (2010), that evaluating the growth of beet throughout the cultivation, verified a linear increase in the number of leaves, presenting an average value of 7.67 leaves per plant at 65 days after transplanting.

There was an increase in the leaf area up to $65 \mathrm{DAE}$, and stabilized until 83 DAE (Figure 1C), with an approximate value of $140 \mathrm{~cm}^{2}$. Corroborating the results found by Gondim et al.
(2010), who observed that the indicative variables of plant development, maintained the same behavior, with growth until the end of the crop cycle.

\section{Effect of humic substances rates, saline water and stages of assessment on physiological parameters}

There was a linear increase in the values of chlorophyll $a, b$ and total, up to 83 DAE (Figure 2A, 2B e 2C), obtaining the highest values of chlorophyll $a$, chlorophyll $b$ and total of 27.81; 9.06 and 36.87 ICF, respectively, indicating that with the advancing age of the plants there was an increase in the index of chlorophyll $a, b$ and total, that is, the leaves changed their color from green to intense green. Chlorophyll is the pigment that absorbs light, and will be used in photosynthesis, these pigments being essential in the transformation of light radiation into chemical energy (Taiz et al., 2017).

Stomatal conductance reduced from $0.26 \mathrm{~mol} \mathrm{H}_{2} \mathrm{O} \mathrm{m}^{-2} \mathrm{~s}^{-1}$ at $36 \mathrm{DAE}$ to $0.12 \mathrm{~mol} \mathrm{H}_{2} \mathrm{O} \mathrm{m}^{-2} \mathrm{~s}^{-1}$ at $57 \mathrm{DAE}$ (Figure. 3A). Possibly, the decrease in stomatal conductance has occurred, as a strategy of the plant to minimize water loss due to high temperature stress (Taiz et al., 2017), inside the greenhouse. The $\mathrm{CO}_{2}$ internal concentration also decreased from 307.90 $\mu \mathrm{mol} \mathrm{m} \mathrm{m}^{-2} \mathrm{~s}^{-1}$ at 36 DAE to $237.24 \mu \mathrm{mol} \mathrm{m}^{-2} \mathrm{~s}^{-1}$ at 57 DAE (Figure 3B). $\mathrm{CO}_{2}$ internal concentration decreased as transpiration rate increased (Figure $3 \mathrm{C}$ ), since both are directly interconnected. According to Taiz et al. (2017) daily carbon gain in photosynthesis is lost by breathing, a loss that tends to double in older plants.

The transpiration rate increased from $1.3 \mathrm{mmol} \mathrm{H}_{2} \mathrm{O} \mathrm{m}^{-2} \mathrm{~s}^{-1}$ at

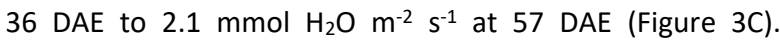
Environmental factors, such as high temperatures in the greenhouse, may have contributed to this increase in the transpiration rate over time. According to Taiz et al. (2017), transpiration increases according to temperature, responding to short-term changes as a function of temperature, varying with plant development and external factors.

\section{Effect of humic substances rates and saline water on soil pH} and electrical conductivity of the saturation paste extract Soil $\mathrm{pH}$ was influenced by the application of humic substances, with a linear increase as the HS rates increased, increasing from 6.03 in the control to 6.69 in the $30 \mathrm{~mL} \mathrm{~L}^{-1} \mathrm{HS}$ rate (Figure 4). The presence of negative charges on the surface of HS from carboxylic and phenolic groups contributes to the increase of the cation exchange capacity, which provides more charge exchange sites to adsorb $\mathrm{H}^{+}$, which raises the $\mathrm{pH}$ (Sposito, 1984). The magnitude of this effect may have been greater due to the sandy texture of this soil, which causes less buffering for $\mathrm{pH}$ variations, as also observed by Yang et al. (2013) in sandy soil.

Irrigation with saline waters did not influence the soil pH, and presented values in agreement with those observed by Garcia et al. (2008), that did not verify changes in the $\mathrm{pH}$ values in an Oxisol, as function of electrical conductivity of irrigation water from 0.5 to $10 \mathrm{dS} \mathrm{m}^{-1}$ in greenhouse.

Irrigation with saline water promoted an increase in ECspe, with the values of $0.68 \mathrm{dS} \mathrm{m}^{-1}$ elevated to $4.10 \mathrm{dS} \mathrm{m}^{-1}$ between the treatments irrigated with CEw of 0.5 and $5.5 \mathrm{dS} \mathrm{m}^{-1}$ waters, respectively (Figure 5), going from non-saline to moderately saline (Richards, 1954). The increase in ECspe is related to the increase in ions activities from saline solutions, such as $\mathrm{Na}^{+}, \mathrm{Ca}^{2+}, \mathrm{Mg}^{2+}$, and $\mathrm{Cl}^{-}$. The increase in $\mathrm{HS}$ rates did not have significant effects on ECspe, obtaining an average of $2.33 \mathrm{dS} \mathrm{m}^{-1}$. 
Table 1. Physical and chemical characteristics of the substrate used in the experiment.

\begin{tabular}{|c|c|c|c|}
\hline \multicolumn{4}{|c|}{ Physical } \\
\hline Attributes & \multicolumn{2}{|c|}{$0-20 \mathrm{~cm}$} & \\
\hline Sand $\left(\mathrm{g} \mathrm{kg}^{-1}\right)$ & \multicolumn{2}{|c|}{607} & $\begin{array}{c}-40 \mathrm{~cm} \\
534\end{array}$ \\
\hline Silt $\left(\mathrm{g} \mathrm{kg}^{-1}\right)$ & \multicolumn{2}{|c|}{56} & 82 \\
\hline Clay $\left(\mathrm{g} \mathrm{kg}^{-1}\right)$ & \multicolumn{2}{|c|}{337} & 384 \\
\hline Textural class & \multicolumn{2}{|c|}{ Sandy clay loam } & Sandy clay loam \\
\hline \multicolumn{4}{|c|}{ Chemical } \\
\hline Attributes & $0-20 \mathrm{~cm}$ & $20-40 \mathrm{~cm}$ & Composite sample \\
\hline $\mathrm{pH}\left(\mathrm{H}_{2} \mathrm{O}: 1: 2,5\right)$ & 5.81 & 5.17 & 6.40 \\
\hline$P\left(\mathrm{mg} \mathrm{dm}^{-3}\right)$ & 18.72 & 8.50 & 26.25 \\
\hline $\mathrm{K}^{+}\left(\mathrm{mg} \mathrm{dm} \mathrm{m}^{-3}\right)$ & 62.61 & 44.94 & 63.03 \\
\hline $\mathrm{Na}^{+}\left(\mathrm{cmol}_{\mathrm{c}} \mathrm{dm}^{-3}\right)$ & 0.07 & 0.05 & 0.19 \\
\hline $\mathrm{Ca}^{2+}\left(\mathrm{cmol}_{\mathrm{c}} \mathrm{dm}^{-3}\right)$ & 2.05 & 1.55 & 3.80 \\
\hline $\mathrm{Mg}^{2+}\left(\mathrm{cmol}_{\mathrm{c}} \mathrm{dm}^{-3}\right)$ & 1.85 & 0.70 & 1.91 \\
\hline $\mathrm{Al}^{3+}\left(\mathrm{cmol}_{\mathrm{c}} \mathrm{dm}^{-3}\right)$ & 0.00 & 1.00 & 0.00 \\
\hline $\mathrm{H}+\mathrm{Al}\left(\mathrm{cmol}_{\mathrm{c}} \mathrm{dm}^{-3}\right)$ & 3.55 & 5.69 & 2.81 \\
\hline Effective CTC $\left(\mathrm{cmol}_{\mathrm{c}} \mathrm{dm}^{-3}\right)$ & 4.13 & 5.60 & 6.06 \\
\hline Potential CTC $\left(\mathrm{cmol}_{\mathrm{c}} \mathrm{dm}^{-3}\right)$ & 7.68 & 10.29 & 8.87 \\
\hline $\mathrm{SB}\left(\mathrm{cmol}_{\mathrm{c}} \mathrm{dm}^{-3}\right)$ & 4.13 & 4.60 & 6.06 \\
\hline $\mathrm{m}(\%)$ & 0.0 & 17.86 & 0.00 \\
\hline $\mathrm{V}(\%)$ & 46.22 & 44.70 & 31.68 \\
\hline Organic matter $\left(\mathrm{g} \mathrm{kg}^{-1}\right)$ & 20.84 & 14.80 & 20.53 \\
\hline
\end{tabular}
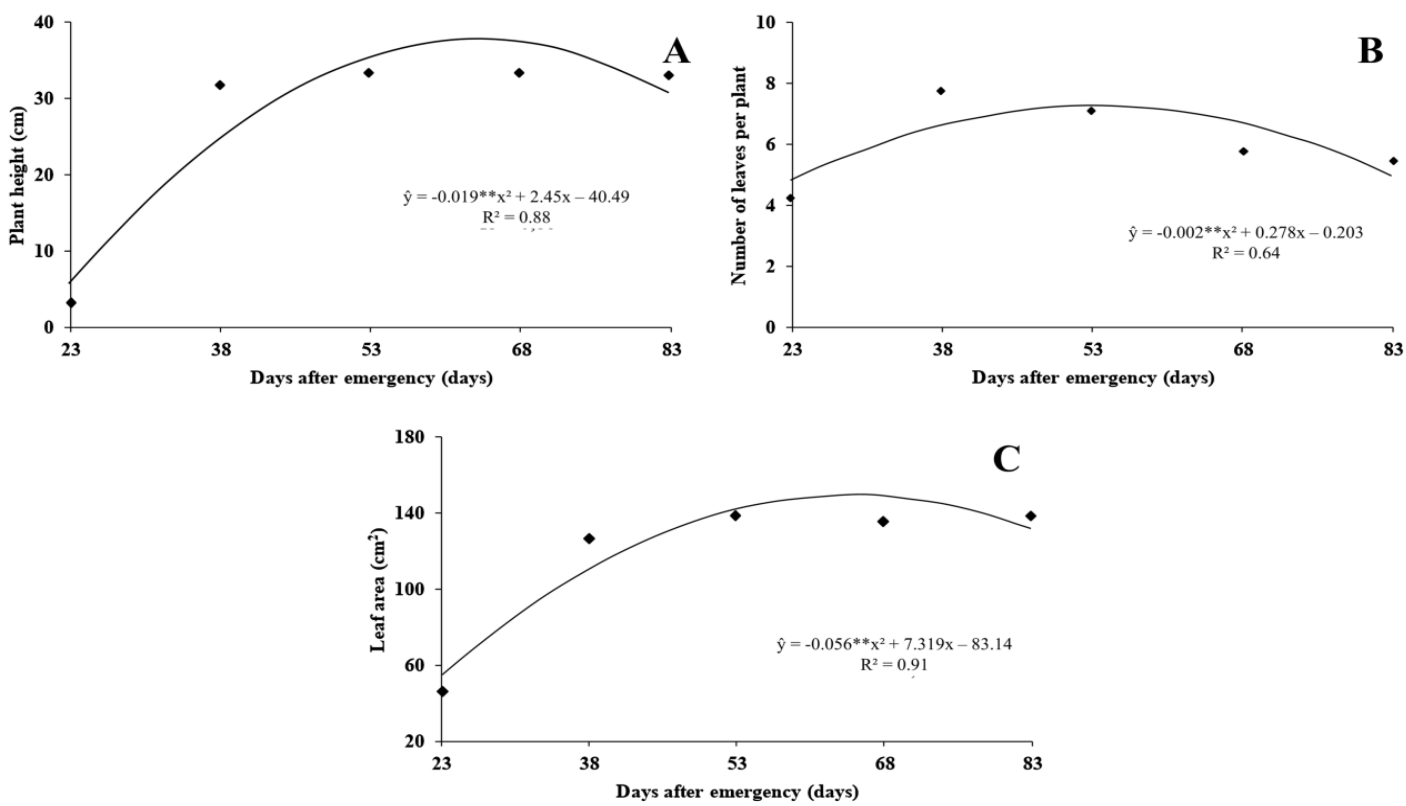

Figure 1. Plant height (A), number of leaves per plant (B), and leaf area (C) of beet plants as a function of stages of assessment (days after emergency).

Table 2. Chemical characterization of non-saline (A1) and saline waters ( $A 2, A 3, A 4, A 5$ and $A 6)$ used in irrigation.

\begin{tabular}{|c|c|c|c|c|c|c|}
\hline \multirow[t]{2}{*}{ Attributes } & \multicolumn{6}{|c|}{ Waters samples } \\
\hline & $\mathrm{A} 1$ & $\mathrm{~A} 2$ & A3 & A4 & A5 & A6 \\
\hline $\mathrm{pH}$ & 6.4 & 6.89 & 7.27 & 7.5 & 7.81 & 7.5 \\
\hline$E C W$ & $\leq 0.50$ & 1.5 & 2.5 & 3.5 & 4.5 & 5.5 \\
\hline $\mathrm{Na}^{+}\left(\mathrm{mmol}_{\mathrm{c}} \mathrm{L}^{-1}\right)$ & 1.13 & 6.48 & 8.79 & 14.84 & 19.1 & 23.02 \\
\hline $\mathrm{K}^{+}\left(\mathrm{mmol}_{\mathrm{c}} \mathrm{L}^{-1}\right)$ & 0.06 & 0.06 & 0.07 & 0.07 & 0.07 & 0.08 \\
\hline $\mathrm{Ca}^{2+}\left(\mathrm{mmol}_{\mathrm{c}} \mathrm{L}^{-1}\right)$ & 0.1 & 0.11 & 0.11 & 0.11 & 0.12 & 0.11 \\
\hline $\mathrm{Mg}^{2+}\left(\mathrm{mmol}_{\mathrm{c}} \mathrm{L}^{-1}\right)$ & 0.11 & 0.17 & 0.11 & 0.14 & 0.13 & 0.18 \\
\hline $\mathrm{Cl}^{-}\left(\mathrm{mmol}_{\mathrm{c}} \mathrm{L}^{-1}\right)$ & 2.8 & 12.3 & 21.2 & 30 & 40.9 & 41.7 \\
\hline $\mathrm{SO}_{4}^{2-}\left(\mathrm{mmol}_{\mathrm{c}} \mathrm{L}^{-1}\right)$ & 2.5 & 3.01 & 3.23 & 3.8 & 3.8 & 6.13 \\
\hline $\mathrm{CO}_{3}^{2-}\left(\mathrm{mmol}_{\mathrm{C}} \mathrm{L}^{-1}\right)$ & 0.0 & 0.0 & 0.0 & 0.0 & 0.0 & 0.0 \\
\hline $\mathrm{HCO}_{3}^{-}\left(\mathrm{mmol}_{\mathrm{c}} \mathrm{L}^{-1}\right)$ & 0.9 & 1.2 & 1.1 & 1.0 & 1.0 & 1.1 \\
\hline SAR & 3.48 & 17.32 & 26.55 & 42.03 & 54.1 & 60.57 \\
\hline
\end{tabular}



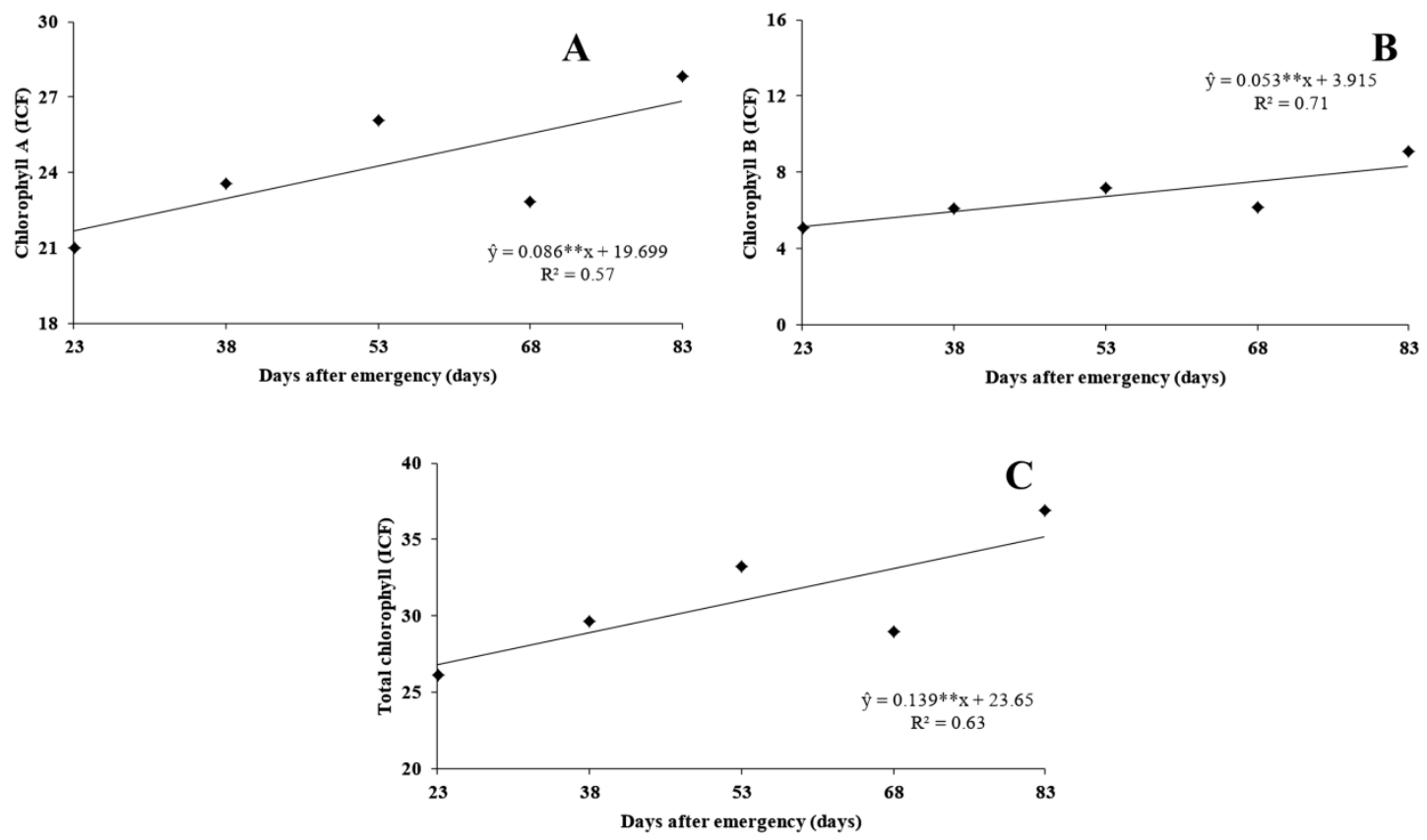

Fig 2. Chlorophyll a (A), chlorophyll b (B) and total chlorophyll (C) of beet plants as a function of stages of assessment (days after emergency).

Table 3. Valores de F para altura de planta, número de folhas e área foliar sob níveis de condutividade elétrica da água de irrigação $(\mathrm{ECW})$, doses de substâncias húmicas (HS), e estágios de avaliação (SoA)

\begin{tabular}{|c|c|c|c|c|}
\hline Sources of variation & DF & Plant height & Number of leaves & Leaf area \\
\hline Blocks & 2 & 2.03 & 1.00 & 10.87 \\
\hline $\mathrm{ECW}$ & 5 & $0.15^{\mathrm{ns}}$ & $1.11^{\text {ns }}$ & $0.13^{\text {ns }}$ \\
\hline HS & 3 & $0.66^{\mathrm{ns}}$ & $0.14^{\text {ns }}$ & $1.44^{\text {ns }}$ \\
\hline SoA & 4 & $3304.08^{* *}$ & $128.98^{* *}$ & $640.85^{* *}$ \\
\hline $\mathrm{ECW} \times \mathrm{HS}$ & 15 & $0.87^{\mathrm{ns}}$ & $0.95^{\mathrm{ns}}$ & $1.04^{\mathrm{ns}}$ \\
\hline ECw $x$ SoA & 20 & $0.70^{\text {ns }}$ & $1.02^{\text {ns }}$ & $0.86^{\text {ns }}$ \\
\hline SH $\times$ SoA & 12 & $0.70^{\text {ns }}$ & $0.84^{\mathrm{ns}}$ & $1.78^{\mathrm{ns}}$ \\
\hline ECW $\times$ HS $\times$ SoA & 60 & $0.78^{\text {ns }}$ & $0.85^{\mathrm{ns}}$ & $0.76^{\mathrm{ns}}$ \\
\hline Error & 238 & 6.94 & 1.36 & 270.39 \\
\hline CV (\%) & & 9.80 & 19.29 & 13.63 \\
\hline
\end{tabular}

ECW: eletrical condutivity of irrigation water; HS: humic substances rates; SoA: stages of assessment; DF: degree of freedom; CV: coefficient of variation.
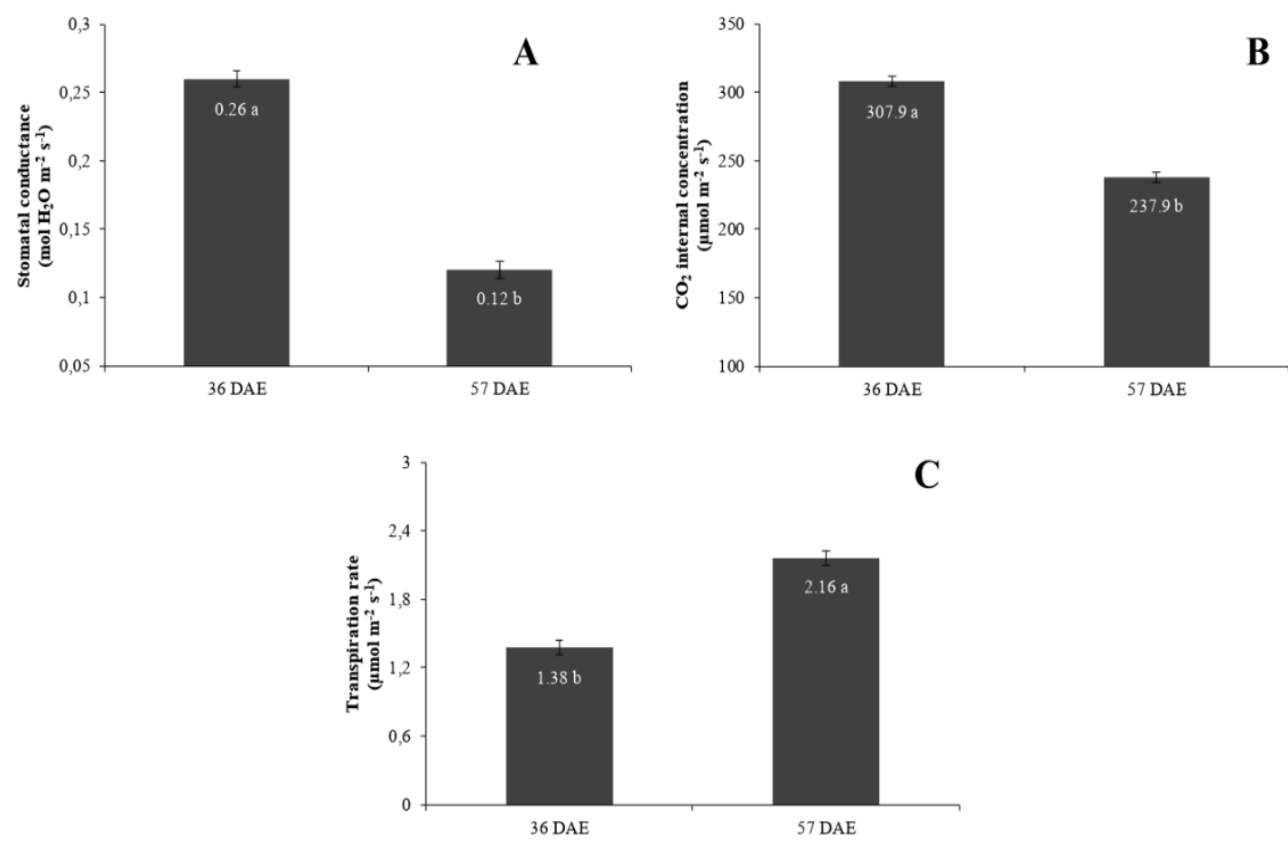

Figure 3. Mean values and standard errors for stomatal conductance (A), $\mathrm{CO}_{2}$ internal concentration (B), and transpiration rate (C) of beet plants at 36 and 57 days after emergency. 
Table 4. Valores de F para os teores de clorofila a (Clo a), clorofila b (Clo b) e clorofila total (Clo total) sob níveis de condutividade elétrica da água de irrigação (ECW), doses de substâncias húmicas (HS), e estágios de avaliação (SoA).

\begin{tabular}{|c|c|c|c|c|}
\hline Sources of variation & DF & Clo a & Clo $b$ & Total Clo \\
\hline Blocks & 2 & 4.93 & 1.11 & 3.24 \\
\hline $\mathrm{ECW}$ & 5 & $0.67^{\text {ns }}$ & $0.31^{\mathrm{ns}}$ & $0.52^{\text {ns }}$ \\
\hline HS & 3 & $1.20^{\mathrm{ns}}$ & $0.90^{\text {ns }}$ & $1.12^{\mathrm{ns}}$ \\
\hline SoA & 4 & $121.75^{* *}$ & $90.02^{* *}$ & $114.42^{* *}$ \\
\hline $\mathrm{ECW} \times \mathrm{HS}$ & 15 & $0.71^{\mathrm{ns}}$ & $0.43^{\text {ns }}$ & $0.56^{\text {ns }}$ \\
\hline ECw $x$ SoA & 20 & $0.96^{\text {ns }}$ & $0.71^{\mathrm{ns}}$ & $0.84^{\mathrm{ns}}$ \\
\hline HS $\times$ SoA & 12 & $1.90^{*}$ & $0.66^{\mathrm{ns}}$ & $1.41^{\mathrm{ns}}$ \\
\hline $\mathrm{ECW} \times \mathrm{SH} \times \mathrm{SoA}$ & 60 & $0.86^{\text {ns }}$ & $0.75^{\mathrm{ns}}$ & $0.81^{\mathrm{ns}}$ \\
\hline Residue & 238 & 5.52 & 2.13 & 13.58 \\
\hline $\mathrm{CV}(\%)$ & & 9.68 & 21.71 & 11.88 \\
\hline
\end{tabular}

ECW: eletrical condutivity of irrigation water; HS: humic substances rates; SoA: stages of assessment; Clo a: Chlorophyll a; Clo b: chlorophyll b; Total clo: total chlorophyll; DF: degree of freedom; CV: coefficient of variation.

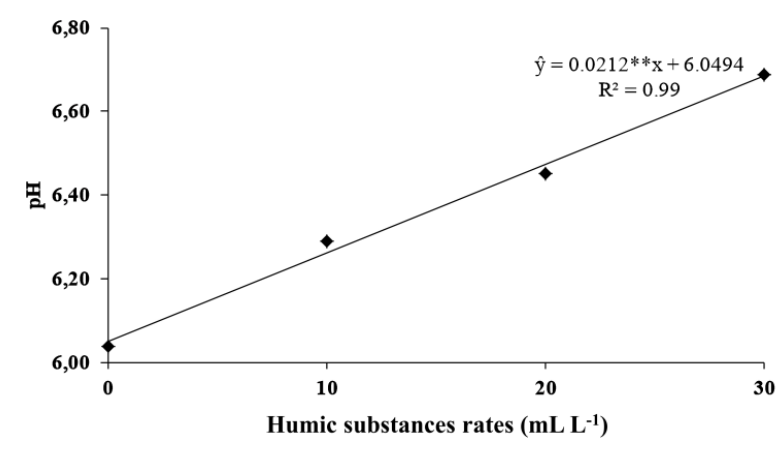

Figure 4. Soil pH as function of humic substance rates.

Table 5. Valores de $\mathrm{F}$ para taxa fotossintética (A), condutância estomática (Gs), conteúdo intercelular de $\mathrm{CO}_{2}(\mathrm{Ci})$, e taxa de transpiração (E) sob níveis de condutividade elétrica da água de irrigação (ECW), doses de substâncias húmicas (HS), e estágios de avaliação (SoA)

\begin{tabular}{|l|c|c|c|c|c|}
\hline Slocks & DF & A & gs & Ci & E \\
\hline ECW & 2 & 20.89 & 12.80 & 44.34 & 31.88 \\
\hline HS & 5 & $1.14^{\text {ns }}$ & $1.08^{\text {ns }}$ & $0.68^{\text {ns }}$ & $1.08^{\text {ns }}$ \\
\hline SoA & 3 & $1.27^{\text {ns }}$ & $3.39^{*}$ & $1.31^{\text {ns }}$ & $2.27^{\text {ns }}$ \\
\hline ECW $\times$ HS & 1 & $0.01^{\text {ns }}$ & $293.45^{* *}$ & $120.67^{* *}$ & $58.35^{* *}$ \\
\hline ECW $\times$ SoA & 15 & $0.90^{\text {ns }}$ & $1.13^{\text {ns }}$ & $2.03^{*}$ & $0.78^{\text {ns }}$ \\
\hline HS $\times$ SoA & 5 & $0.62^{\text {ns }}$ & $1.26^{\text {ns }}$ & $0.11^{\text {ns }}$ & $0.83^{\text {ns }}$ \\
\hline ECW $\times$ HS $\times$ SoA & 3 & $0.65^{\text {ns }}$ & $0.25^{\text {ns }}$ & $0.27^{\text {ns }}$ & $0.36^{\text {ns }}$ \\
\hline Error & 15 & $0.60^{\text {ns }}$ & $0.48^{\text {ns }}$ & $0.53^{\text {ns }}$ & $0.62^{\text {ns }}$ \\
\hline CV(\%) & 94 & 3.80 & 0.002 & 148.50 & 0.37 \\
\hline
\end{tabular}

ECw: eletrical condutivity of irrigation water; $\mathrm{HS}$ : humic substances rates; SoA: stages of assessment; A: net photosynthesis; Gs: stomatal conductance; $\mathrm{Cl}_{\text {: }} \mathrm{CO}_{2}$ internal concentration; $\mathrm{E}$ : transpiration rate; DF: degree of freedom; CV: coefficient of variation.

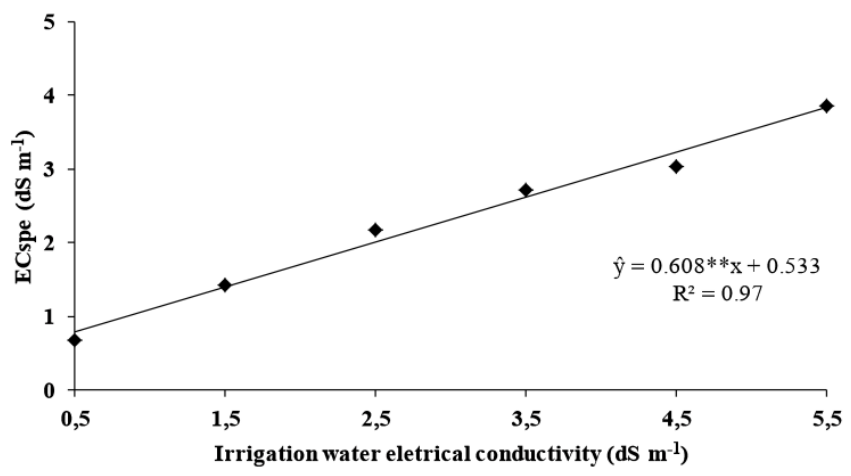

Figure 5. Electrical conductivity of saturated paste extract as irrigation water electrical conductivity. 
Table 6. Valores de F para o pH do solo $(\mathrm{pH})$ e a condutividade elétrica na pasta de saturação (ECspe) sob níveis de condutividade elétrica da água de irrigação (ECW) e doses de substâncias húmicas (HS).

\begin{tabular}{|l|c|c|c|}
\hline Sources of variation & DF & pH & $3.10^{\text {ns }}$ \\
\hline Blocos & 2 & $0.58^{\text {ns }}$ & $1.20^{\text {ns }}$ \\
\hline ECW & 5 & $10.41^{* *}$ & $50.76^{* *}$ \\
\hline HS & 3 & $0.82^{\text {ns }}$ & $0.57^{\text {ns }}$ \\
\hline ECW x HS & 15 & 0.09 & 0.30 \\
\hline Error & 46 & 4.8 & 23.5 \\
\hline CV (\%) & & $1.04^{\text {ns }}$ & \\
\hline ECw: eletrical condutivity of irrigation water; HS: humic substances rates; ECspe: electrical conductivity of saturated paste extract; DF: degree of freedom; CV: coefficient of variation.
\end{tabular}

\section{Material and methods}

\section{Location of experimental area}

The experiment was conducted in a greenhouse located at the Center for Human and Agricultural Sciences (CCHSA), Campus III of the Federal University of Paraíba (UFPB), in Bananeiras - PB, located at the geographical coordinates $6^{\circ} 45^{\prime} \mathrm{S}$ and $35^{\circ} 37^{\prime} \mathrm{W}$ and $520 \mathrm{~m}$ altitude. The average temperature inside the greenhouse was $34^{\circ} \mathrm{C}$, and the air humidity ranged from 29 to $59 \%$.

\section{Experiment installation and conduction}

The experimental design adopted was in randomized blocks, in six repetitions in a $6 \times 4 \times 5$ factorial scheme, referring to six electrical conductivities of irrigation water $(E C W): 0.5 ; 1.5$; $2.5 ; 3.5 ; 4.5$ and $5.5 \mathrm{dS} \mathrm{m}^{-1}$, four humic substances rates (HS) (0; $10 ; 20$ and $30 \mathrm{ml}$ per plant), and five stages of assessment $(23,38,53,68$ and 83 days after emergency).

The experimental units were composed of pots with a volumetric capacity of $5 \mathrm{dm}^{3}$. The pots were arranged in a spatial arrangement of $30 \mathrm{~cm}$ between rows and $15 \mathrm{~cm}$ between rows, on a black plastic canvas, so that they were not in direct contact with the soil of the greenhouse.

The soil was collected in the $0-20$ and $20-40 \mathrm{~cm}$ layers in the Agriculture Sector of CCHSA-UFPB, and were analyzed chemically and physically according to Donagema et al. (2011) (Table 1), and the pots was filled with the mixture of soil from the two layers. The soil was classified as Oxisol (IUSS Working Group WRB, 2014; Santos et al., 2018).

Beet seeds cv. 'Maravilha' were sown directly in the pots at a depth of $2 \mathrm{~cm}$, placing three seeds in each pot, and at 15 days after emergence thinning was carried out, leaving only the most vigorous seedling.

Irrigation was carried out daily in the early morning, in order to maintain the soil in the field capacity, in order to ensure the emergence and development of seedlings. The applied water level was calculated using the values of crop evapotranspiration, estimated for each stage of plant development from the reference evapotranspiration (ETo) obtained from the agrometeorological station near the experimental area, and the culture coefficient $(\mathrm{Kc})$ adapted for environments protected.

The preparation of the waters with each electrical conductivity was performed weekly by the addition of $\mathrm{NaCl}$, $\mathrm{CaCl}_{2} .2 \mathrm{H}_{2} \mathrm{O}$ and $\mathrm{MgCl}_{2} \cdot 6 \mathrm{H}_{2} \mathrm{O}$, in the proportion of $7: 2: 1$ (Rhoades et al., 2000). From this solution, the solutions with the proposed ECW were prepared: $1.5 ; 2.5 ; 3.5 ; 4.5$ and $5.5 \mathrm{dS}$ $\mathrm{m}^{-1}$ using a portable conductivimeter to measure values. The waters used for irrigation were analyzed for salinity (Tabela 2).

The source of humic substances was the commercial product Humitec $^{\circledast}$, without granulometric specifications, soluble in water with solubility of $100 \mathrm{~g} \mathrm{l}^{-1}$, containing $68 \%(\mathrm{w}: \mathrm{w})$ of total humic extract; $31 \%$ (w:w) organic carbon; $52 \%$ (w:w) humic acids; $16 \%$ (w:w) fulvic acids; and 17\% (w:w) of water-soluble potassium $\left(\mathrm{K}_{2} \mathrm{O}\right)$. The humic substances rates were fractionated and applied manually at 7, 26 and 45 days after transplanting at rates of 10,20 and $30 \mathrm{ml} /$ plant, adding $10 \mathrm{ml}$ of $100 \mathrm{mmol}$ citric acid for each 1 liter of the solution.

Fertilization with NPK was carried out at rates of 40, 180 and $90 \mathrm{~kg} \mathrm{ha}^{-1}$ of $\mathrm{N}, \mathrm{P}_{2} \mathrm{O}_{5}$ and $\mathrm{K}_{2} \mathrm{O}$, respectively, according to the "Recommendations for fertilizing for the State of Pernambuco" (Cavalcanti, 2008), using urea, simple superphosphate and potassium chloride as sources of fertilization. The NPK rates were diluted and applied as a solution, divided into three times, on the foundation, at 28 and 56 DAE.

\section{Evaluated characteristics}

The effects of treatments on the beet culture were evaluated through growth analysis: plant height (using a ruler graduated in $\mathrm{cm}$ ), number of leaves (manual counting) and leaf area, using the model proposed for the cultivation of beet: $L A=$ $0.5083 *$ LW +31.928 (Tsialtas e Maslaris, 2008), with LA = leaf area $\left(\mathrm{cm}^{2}\right), L W=$ product of the length $(\mathrm{cm})$ and width (cm) of the leaf); and physiological analyzes: chlorophyll index ( $a, b$ and total), stomatal conductance, transpiration rate, net photosynthesis and $\mathrm{CO}_{2}$ internal concentration.

The determination of chlorophyll index $a, b$ and total was carried out by the non-destructive method at $23 ; 38 ; 53 ; 68$ and 83 days after emergency, using a portable chlorophyll meter (ClorfiLOG ${ }^{\circledR}$, model CFL 1030) (Falker, 2008). Readings were performed on the middle part of the fully expanded leaf of each plant and on all plants per plot, between 9:30 and 10 a.m.

Stomatal conductance ( $\mathrm{mol}$ of $\mathrm{H}_{2} \mathrm{O} \mathrm{m}^{-2} \mathrm{~s}^{-1}$ ), transpiration rate ( $\mathrm{mmol}$ of $\mathrm{H}_{2} \mathrm{O} \mathrm{m}^{-2} \mathrm{~s}^{-1}$ ), net photosynthesis $\left(\mu \mathrm{mol} \mathrm{m} \mathrm{m}^{-2} \mathrm{~s}^{-1}\right.$ ) and $\mathrm{CO}_{2}$ internal concentration $\left(\mu \mathrm{mol} \mathrm{m} \mathrm{m}^{-2} \mathrm{~s}^{-1}\right)$ were obtained through readings at 36 and 57 DAE using the infrared gas analyzer (IRGA) model LCpro + System.

At $83 \mathrm{DAE}$, after the last determination of growth and physiological analyzes of beet plants, soil samples were collected from each experimental unit to assess the electrical conductivity of the saturation paste extract and the soil $\mathrm{pH}$ (Richards, 1954).

\section{Data analysis}

The data were submitted to analysis of variance by the $\mathrm{F}$ test at $5 \%$ probability. For measurements with a quantitative nature (electrical conductivity of irrigation water and humic substances rates) polynomial regression analysis was performed, and the best fit was considered to be the one with the highest $R^{2}$ value and the lowest residual square sum value. For measurements with a qualitative nature, as days after emergency $t$ test was performed. All analyzes were 
performed using the software SAS University Edition (Cody, 2015).

\section{Conclusions}

Salinity in irrigation water reduces growth, chlorophyll a levels and stomatal opening of beet plants.

The application of humic substances above $30 \mathrm{ml} /$ plant promotes a decrease in the fresh matter of the beet root.

The application of humic substances reduces the $\mathrm{pH}$ in sandy acidic soils.

\section{Acknowledgements}

The authors would like to thank the Federal University of Paraiba (UFPB) and the Coordination for the Improvement of Higher Education Personnel (CAPES) for scholarships concessions.

\section{References}

Ali AYA, Ibrahim MEH, Zhou G, Nimir NEA, Jiao X, Zhu G, Elsiddig AMI, Zhi W, Chen X, Lu H (2019) Ameliorative effects of jasmonic acid and humic acid on antioxidant enzymes and salt tolerance of forage sorghum under salinity conditions. Crop Ecol Physiol. 3(6):3099-3108.

Alves AU, Prado RM, Gondim ARO, Fonseca IM, Cecílio Filho AB (2008) Desenvolvimento e estado nutricional da beterraba em função da omissão de nutrientes. Hortic Bras. 26(2):292 - 295.

Aydin A, Kant C, Turan M (2012) Humic acid application alleviate salinity stress of bean (Phaseolus vulgaris L.) plants decreasing membrane leakage. Afr J Agr Res. 7(7): 1073-1086.

Canellas LP, Olivares FL, Okorokova-Façanha AL, Façanha AR (2002) Humic acids isolated from earthworm compost enhance root elongation, lateral root emergence, and plasma membrane $\mathrm{H}^{+}$-ATPase activity in maize roots. Plant Physiol. 130:1951-1957.

Cavalcanti FJA (Coord.) (2008) Recomendações de adubação para o Estado de Pernambuco: 2ª aproximação. 3rd edn. IPA: Recife.

Cody R (2015) An introduction to SAS University Edition. SAS Institute: Cary-NC.

Donagema GK, Campos DVB, Calderano SB, Teixeira WG, Viana JHM (Orgs) (2011) Manual de métodos de análise do solo. 2nd. rev. Embrapa Solos: Rio de Janeiro.

Falker Automação Agrícola Ltda (2008) Manual do medidor eletrônico de teor clorofila (ClorofiLOG/CFL 1030). Falker Automação Agrícola: Porto Alegre.

Freire MB, Miranda MF, Oliveira EE, Silva LE, Pessoa LG, Almeida BG (2014) Agrupamento de solos quanto à salinidade no Perímetro Irrigado de Custódia em função do tempo. Rev Bras Eng Agric Amb. 18:86-91.

Garcia GO, Martins Filho S, Reis EF, Moraes WB, Nazário AA (2008) Alterações químicas de dois solos irrigados com água salina. Rev Cienc Agron. 39(1):7-18.

Gondim ARO, Flores MEP, Martinez HEP, Fontes PCR, Pereira PRG (2010) Condutividade elétrica na produção e nutrição de alface em sistema de cultivo hidropônico NFT. Biosci J. 26:894-904.

Hatami E, Shokohian AA Ghanbari AR, Naseri LA (2018) Alleviating salt stress in almond rootstocks using og humic acid. Sci Hortic. 237:296-302.

IUSS Working Group WRB (2015) World Reference Base for Soil Resources 2014, update 2015 International soil classification system for naming soils and creating legends for soil maps. World Soil Resources Reports No. 106. FAO: Rome.

Jarošová M, Klejdus B, Kováčik J, Babula P, Hedbavny J (2016) Humic acid protects barley against salinity. Acta Physiol Plant. 38:161-169.

Karakurt Y, Ozdamar-Unlu H, Unlu H, Tonguc M (2015) Antioxidant compounds and activity in cucumber fruit in response to foliar and soil humic acid application. Eur J Hortic Sci. 80 (2): 76-80.

Kaya C, Akram NA, Ashraf M, Sonmez O (2017) Exogenous application of humic acid mitigates salinity stress in maize (Zea mays L.) plants by improving some key physico-biochemical attributes. Cereal Res Comm. 46:67-78.

Khaled H, Fawy HA (2011) Effect of different levels of humic acids on the nutrient content, plant growth, and soil properties under conditions of salinity. Soil Water Res. 6(1):21-29.

Mora V, Eva B, Angel-Maria Z, Aguirre E, Garnica M, Fuentes M (2010) Action of humic acid on promotion of cucumber shoot growth involves nitrate-related changes associated with the root-to-shoot distribution of cytokinins, polyamines and mineral nutrients. J Plant Physiol. 167:633-642.

Nardi S, Pizzeghello D, Muscolo A, Vianello A (2002) Physiological effects of humic substances on higher plants. Soil Biol Biochem, 34:1527-36.

Rassam G, Dadkhah A, Yazdi AK, Dashti M (2015) Impacto f humic acid on yield and quality of sugar beet (Beta vulgaris L.) grown on calcareous soil. Not Sci Biol. 7(3):367-371.

Richards LA (1954) Diagnostico y rehabilitación de suelos salinos y sódicos. Departamento de Agricultura de los Estados Unidos de América: Mexico.

Rhoades JP, Kandiah A, Mashali AM (2000) The use saline waters for crop production. Translated: Gheyi HR, Sousa JR, Queiroz JE. UFPB: Campina Grande.

Saidimoradi D, Ghaderi N, Javadi T (2019) Salinity stress mitigation by humic acid application in strawberry (Fragaria $x$ ananassa Duch.). Sci Hortic. 256:108594.

Sani B. (2014) Foliar application of humic acid on plant height in canola. APCBEE Procedia. 8:82-86.

Santos HG, Jacomine PKT, Anjos LHC, Oliveira VA, Lumbreras JF, Coelho MR, Almeida JA, Araujo Filho JC, Oliveira JB, Cunha TJF. (2018) Sistema Brasileiro de Classificação de Solos. 5th ed. EMBRAPA: Brasília.

Sposito G (1984) The surface chemistry of soils. Oxford University: NewYork.

Taiz L, Zeiger E, Møller IM, Murphy (2017) A. Fisiologia e desenvolvimento vegetal. 6 rd. Artmed: Porto Alegre.

Tsialtas JT, Maslaris N (2008) Leaf area prediction model for sugar beet (Beta vulgaris L.) cultivars. Photosynthetica, 46:291-293.

Yang S, Zhang Z, Cong L, Wang X, Shi S (2013) Effect of fulvic acid on the phosphorus availability in acid soil. J Soil Sci Plant Nutr. 13(3):526-533.

Wilczewski E, Szczepanek M, Wenda-Piesik A (2018) Response of sugar beet to humic substances and foliar fertilization with potassium. J Cent Eur Agric. 19(1):153-165.

Zandonadi DB, Santos MP, Medici LO, Silva J (2014) Ação da matéria orgânica e suas frações sobre a fisiologia de hortaliças. Hortic Bras. 32:14-20.

Zandonadi DB, Canellas LP, Façanha AR (2007) Indolacetic and humic acids induce lateral root development through a concerted plasmalemma and tonoplast $\mathrm{H}^{+}$pumps activation. Planta 225:1583-1595.

Zulfiqar I, Zahid NY, Qureshi AA, Hafiz IA (2019) Impact of biostimulants to improve the growth of local fennel (Foeniculum vulgare) under salinity stress. J Pure Appl Agric. 4(1):38-50. 